\title{
Low Wind Speed Technology Phase II: Offshore Floating Wind Turbine Concepts: Fully Coupled Dynamic Response Simulations
}

\section{Massachusetts Institute of Technology}

Project Description: Floating wind energy systems have emerged as a promising technology for the utilization of offshore wind resources for large-scale electricity generation near major load centers. Drawing upon the maturity of wind turbine technologies as well as floater technologies developed by the oil and gas industry, wind turbine manufacturers are developing multimegawatt systems for offshore operation.

This study employs dynamic response simulations to evaluate at least two floating platform concepts for offshore wind turbines deployed in water depths between 50 and 200 meters, a moored spar buoy and a tension leg buoy. One component of this study is the selection of wind turbine, floater, mooring system, and foundation configurations based on considerations of reliability and economy. A second component is to propose standard theoretical and experimental methods for designing floating wind turbines for operation over extended periods in severe offshore environments. These methods will address stability issues that arise from combined turbulent wind and random wave loading.

\section{Project Type: \\ Total Project Budget: \\ Conceptual Design Study \\ Industry Cost Share: \\ $\$ 178,920$ \\ DOE Cost Share: \\ $\$ 0$ \\ $\$ 178,920$ \\ Planned Project Duration: August 2004-February 2006}

\section{Contacts:}

\section{NREL/Sandia Contact:}

Sandy Butterfield, NREL 1617 Cole Blvd.

Golden, Colorado 80401

303-384-6902

sandy_butterfield@nrel.gov

\section{MIT Contact:}

Professor Paul Sclavounos, 5-320

Department of Mechanical Engineering, MIT

77 Massachusetts Ave.

Cambridge, Massachusetts 02139

617-253-4364

pauls@mit.edu

Project Underway

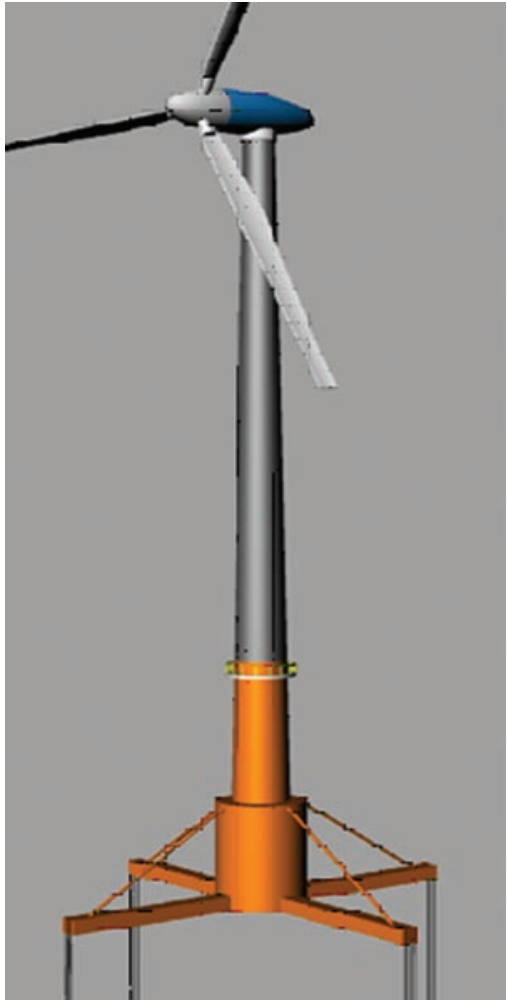

Floating platform concept illustration/simulation.

Current Status:

\begin{abstract}
A Strong Portfolio for a Strong America • Energy efficiency and clean, renewable energy will mean a stronger economy, a cleaner environment, and greater energy independence for America. Working with a wide array of state, community, industry, and university partners, the U.S. Department of Energy's Office of Energy Efficiency and Renewable Energy invests in a diverse portfolio of energy technologies.
\end{abstract}

For more information contact EERE Information Center • 1-877-EERE-INF (1-877-337-3463) • www.eere.energy.gov 